\title{
Determination of Biogas Energy Potential of Aegean Region Based on Animal Waste
}

\author{
Zuhal Akyürek ${ }^{1 *}$, Semih Coşkun² \\ ${ }^{1}$ Burdur Mehmet Akif Ersoy University, Faculty of Engineering and Architecture, 15030, Burdur, Turkey. \\ ${ }^{2}$ Pamukkale University, Faculty of Engineering, 20160, Denizli, Turkey. \\ *drzuhalakyurek@gmail.com \\ Received: 06 December 2018 \\ Accepted: 08 May 2019 \\ DOI: $10.18466 /$ cbayarfbe. 492880
}

\begin{abstract}
Biogas is one the promising sustainable energy options due to high availability of organic wastes. Turkey is an energy importer country and diversification of the energy production with indigenous resources is vital for energy security. In Turkey, agricultural activities and livestock farming have important economic value. Biogas production from anaerobic digestion of organic wastes such as livestock manure is of great importance for renewable energy production and waste management for health and environmental protection. In this study, the animal manure based biogas potential, energy value, greenhouse gas emission reduction potential and organic fertilizer generation capacity of the Aegean Region of Turkey were determined. The region is composed of eight provinces including Afyonkarahisar, Aydın, Denizli, İzmir, Manisa, Muğla, Kütahya, and Uşak. The results revealed that Aegean Region has 528 million $\mathrm{m}^{3} /$ year biogas potential corresponding to $2.64 \mathrm{TWh}$ energy generation capacity. In addition, $0.6 \mathrm{million}$ ton/year of organic fertilizer can be produced as the residual of the biogas plants. Utilization of animal wastes in biogas generation plants can contribute to the global climate change combat by reducing $\mathrm{CO}_{2}$ emissions about 4.6 million tons/year. Within the Aegean Region, Manisa has shown the highest biogas potential whereas İzmir has the highest amount of organic fertilizer production potential.
\end{abstract}

Keywords: Biogas, livestock manure, renewable energy, waste management.

\section{Introduction}

Depletion of the fossil fuel reserves, growing energy demand and increasing concerns on energy security and climate change have boosted the interest on renewable energy resources. In response to rising energy demand and anthropogenic emissions, countries have been shifting their energy policies to produce cleaner energy from sustainable resources and technologies. Among the renewables, biomass is the most reliable and cost effective option to cope with environmental impacts of fossil fuel combustion [1-3]. The share of energy production from biomass accounts for $14 \%$ of all energy resources and expected to rise in the following years [4].

The term biomass describes organic materials derived from agricultural activities and industrial, livestock and domestic wastes [5]. Biomass can be converted into useful energy by different conventional technologies such as combustion, pyrolysis, gasification, anaerobic digestion, etc. depending on the fuel properties and the desired end product. Anaerobic digestion is one of the attractive renewable routes for energy conversion of biomass potential [6]. Anaerobic digestion is the microbiological degradation of organic matter of the waste in the absence of oxygen. Biogas which is the end product of anaerobic digestion of organic materials, is a colorless, odorless, combustible gas. Biogas is composed of methane $(35-75 \%)$, carbon dioxide (25-65\%), hydrogen (1-5\%), water vapor, ammonia, hydrogen sulfide and halides in minor quantities [7]. The digestate of the process is the nutrient rich organic fertilizer.

In Turkey, agricultural activities and livestock farming have high economic potential. About 8.6 MTOE of biomass energy [8] can be generated from agricultural, animal and urban wastes in Turkey in order to reduce the strong dependency on imported energy and to reach the envisaged 2023 targets of greenhouse gas emission reduction. The abundancy of biomass signifies its potential for renewable energy production in Turkey [9]. Biogas is one of the most promising technologies in Turkey. The biogas plants in the country has increased to total installed capacity of 322 MWe [10].

Mismanagement of manure may lead to pollution of surface waters which results in eutrophication due to high nutrient concentrations in manure that create an ecological imbalance in the water system [11]. Therefore, valorization of livestock manure through anaerobic digestion (AD) technology can be an effective way to prevent waste disposal problems in livestock farming. It also provides renewable energy production and hence contributes regional economic development. Livestock 
manure is one of the favorable substrates for anaerobic digestion process due to its high moisture and volatile solids contents. Although there are some studies available on various kind of waste potential in different parts of Turkey [9, 12-16] there is no investigation on determination of biogas potential from the available livestock waste inventory in Aegean Region of Turkey. Therefore, this study aims to determine the animal waste (cattle manure, small ruminant and poultry) derived biogas and energy recovery potential of Aegean Region of Turkey. The results are presented in terms of biogas production, energy equivalence, greenhouse gas reduction and organic fertilizer production potentials.

\section{Materials and Methods}

In this study, the animal manure based biogas potential, energy production, greenhouse gas emission reduction and the amount of organic fertilizer production potentials in Aegean Region of Turkey are determined. Aegean Region occupies the western part of Turkey. Its climate is similar to Mediterranean Region with rainy winters, hot and dry summers at the coast and cold, snowy winters, hot and dry summers in the interior. The region is composed of the eight provinces including Afyonkarahisar, Aydın, Denizli, İzmir, Kütahya, Manisa, Muğla and Uşak.

Aegean coast has fertile lands where many kinds of agricultural production takes place. Livestock farming has also huge contribution to the economy of the Region. For estimating the biogas potential from animal waste, the cattle, small ruminant and poultry population in the region are provided from Turkish Statistical Institute [17]. The distribution of number of animals among the provinces is shown Figure 1. The amount of animal inventory was used to calculate the animal waste potential of the provinces. The factors that affecting the animal waste and biogas production potentials in the livestock processing are animal body weight, availability, the ratio of total solids and total volatile solids of the waste, etc. Table 1 shows the typical waste characteristics of different livestock. As seen from Figure 1, cattle population prevails in İzmir province. Small ruminant and poultry population on the other hand, are concentrated in Manisa province.

Biogas potential generated from the livestock manure is calculated as follows [9]:

$$
T B P=M \times T S \times V T S \times A C \times E B_{V T S}
$$

where TBP represents the amount of biogas production potential (m3/year),

$\mathrm{M}$ is the amount of manure based waste potential (kg/year)

TS denotes the total solids ratio in livestock manure,

VTS is the volatiles ratio in total solids of the waste,
AC represents the ratio of availability (cattle, 65\%; small ruminants, $13 \%$; poultry, 99\%) [18].

$\mathrm{EB}_{\mathrm{VTS}}$ is the estimated amount of biogas per unit $\mathrm{kg}$ of the volatile total solids $\left(\mathrm{m}^{3} / \mathrm{kg}\right.$ VTS $)$.

(a)

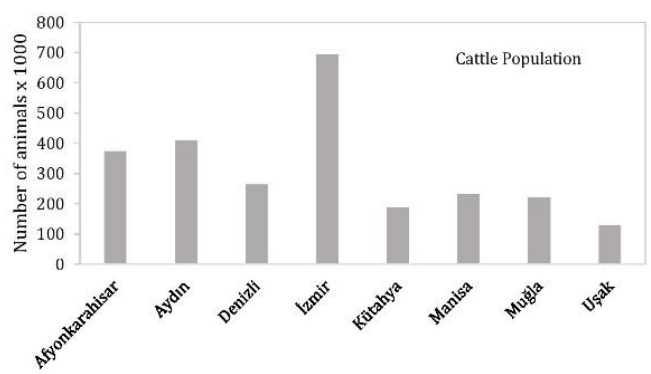

(b)

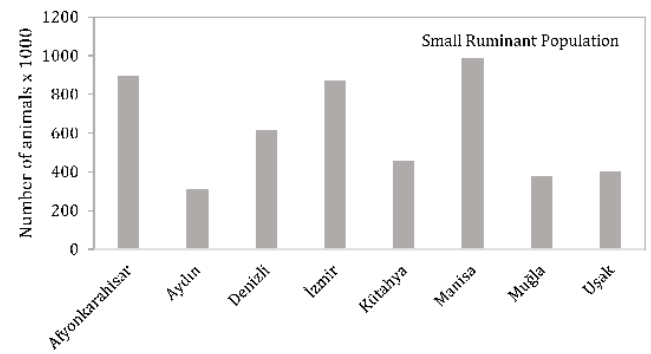

(c)

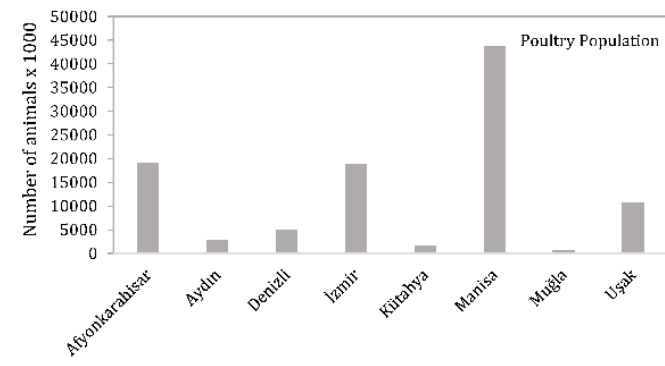

Figure 1. Animal population in the Aegean Region [17].

\section{Results and Discussions}

Energy recovery from local and renewable resources is advantageous to cope with the growing demand for energy and to reduce the share of imported energy sources. Huge amount of livestock waste is being produced in Turkey and its disposal is a major problem. This significant waste inventory shall be utilized for waste management and energy production purposes. 
Table 1. Waste Characteristics [16, 18].

\begin{tabular}{|l|l|l|l|l|}
\hline Animal Type & Fertilizer (kg/day) & $\begin{array}{l}\text { Total Solids } \\
\text { (TS \%) }\end{array}$ & $\begin{array}{l}\text { Volatile Total } \\
\text { Solids (VTS \%) }\end{array}$ & $\begin{array}{l}\text { Biogas Yield } \\
\left(\mathbf{m}^{3} / \mathbf{k g ~ V T S}\right)\end{array}$ \\
\hline Cattle & $10-25$ & $10-20$ & $75-85$ & $100-300$ \\
\hline Small Ruminant & $2-4$ & $25-30$ & $70-80$ & $10-50$ \\
\hline Poultry & $0.05-0.1$ & $40-60$ & $60-80$ & $300-500$ \\
\hline
\end{tabular}

In this study the potential of biogas production in the Aegean Region of Turkey has been determined by using the animal inventory data acquired from Turkish Statistical Institute [17]. The animal waste inventory and calculated biogas potential of livestock manure values of provinces in Aegean Region are presented in Table 2.

Table 2. The amount of animal waste and estimated biogas potential of Aegean Region.

\begin{tabular}{|l|c|c|}
\hline Province & $\begin{array}{c}\text { Available } \\
\text { Waste, } \\
\text { Million } \\
\text { ton/year }\end{array}$ & $\begin{array}{c}\text { Biogas } \\
\text { Potential, } \\
\text { Million m/year }\end{array}$ \\
\hline Afyonkarahisar & 2.64 & 88.63 \\
\hline Aydın & 2.37 & 48.84 \\
\hline Denizli & 1.74 & 42.32 \\
\hline İzmir & 4.48 & 122.27 \\
\hline Kütahya & 1.09 & 22.21 \\
\hline Manisa & 2.46 & 140.81 \\
\hline Muğla & 1.16 & 20.56 \\
\hline Uşak & 1.05 & 42.59 \\
\hline Total & 17.00 & 528.22 \\
\hline
\end{tabular}

As can be seen from the table animal waste potential is the highest in İzmir province however, the biogas potential is the greatest in Manisa province. This is due to high poultry population and hence high amount of poultry waste in Manisa, having greater biogas conversion potential with respect to cattle manure and small ruminant manure (Table 1). Animal manure potential obtained from the farm animals in the Region annually has about 528 Million $\mathrm{m}^{3}$ of biogas production capacity. By assuming the methane percent in biogas about $50 \%, 264.11$ Million $\mathrm{m}^{3}$ of methane can be produced to be directly combusted in gas fired boilers. This is an indicative of advantageous utilization of animal manure in anaerobic digestion systems for green energy production.

Estimated potential of energy production from the livestock manure is presented in Figure 2. As seen from the figure, Manisa province has highest energy generating capacity (27\%) followed by İzmir (23\%) and Afyonkarahisar $(17 \%)$ provinces.

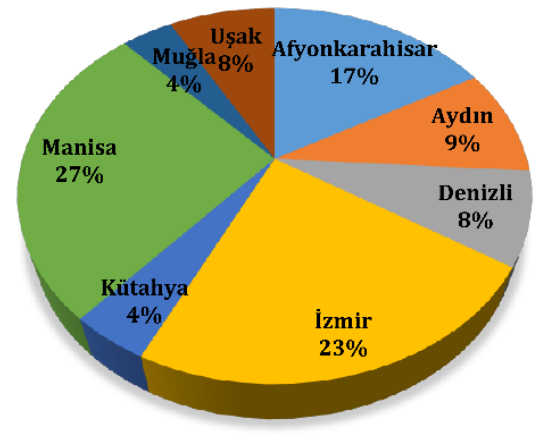

Figure 2. Distribution of biogas energy potential among the provinces in Aegean Region.

Total annual biogas energy potential from animal manure has estimated as 2.64 TWh corresponding to 81.8 Thousand Tons of Oil Equivalence.

Methane gas naturally produced and emitted when the livestock waste that is not collected and treated in anaerobic digestion systems [19]. Methane gas has 25 times more environmental destruction potential than carbon dioxide. Therefore, processing of manure is of great importance in terms of non-carbon dioxide emission reduction. The carbon dioxide equivalents of the estimated methane emissions were calculated by using global warming impact of methane relative to carbon dioxide with a 100-year time horizon [20]. The avoided methane emissions from biogas conversion correspond to 4.6 million ton/year equivalent carbon dioxide emission reduction.

The residual of the biogas production plant is organic fertilizer, rich in nitrogen and nutrients. The amount of organic fertilizer production from anaerobic digestion of animal manure in Aegean Region is shown in Figure 3. As can be seen from the figure, İzmir province has the highest fertilizer production potential due to its high cattle population. The region has totally about 0.6 million tons of annual organic fertilizer production potential.

Considering the huge animal waste potential in the region, biogas production can be an advantageous and environmentally friendly route in meeting the heat and electricity demand to improve the human life standards in rural areas and to promote sustainable development of the region. 


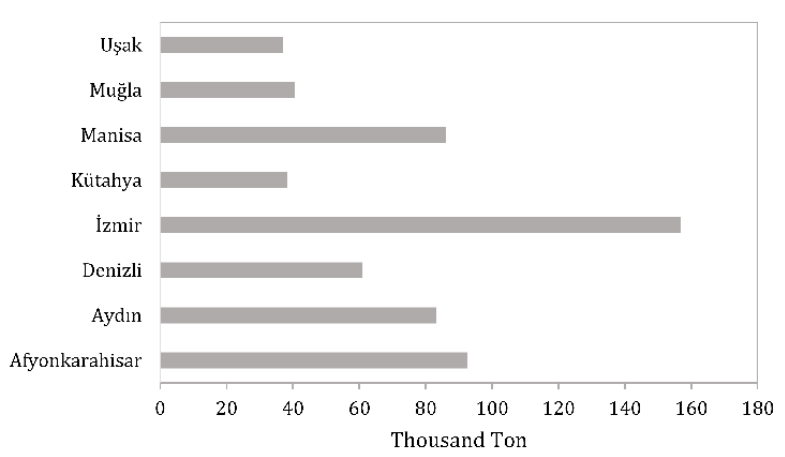

Figure 3. Organic fertilizer production potential in Aegean Region.

\section{Conclusion}

Livestock manure is a problematic waste that needs to be treated to sustain environment and human health. In this study the livestock manure potential of Aegean Region of Turkey was examined. Cattle manure, small ruminants and poultry manure potentials are evaluated for biogas, energy and organic fertilizer productions. The Region has annual 528 million $\mathrm{m}^{3}$ of biogas production capacity from animal manure corresponding to 2.64 TWh energy generation. Manisa Province has shown the highest biogas potential in the region. Biogas production from livestock waste in Aegean Region can reduce annual $\mathrm{CO}_{2}$ emission by 4.6 million tons and contributes to greenhouse gas reduction targets of Turkey. The region annually has 0.6 million tons of fertilizer production potential. İzmir Province has the highest potential of fertilizer production. Calculation of the biogas potential of the Region can further be improved by experimental studies via bio-methane potential analysis of the feedstock. In conclusion, biogas derived from livestock manure is a promising waste management and renewable energy production option in Aegean Region of Turkey.

\section{Acknowledgement}

This research did not receive any specific grant from funding agencies in the public, commercial, or not-forprofit sectors.

\section{Author's Contributions}

Zuhal Akyürek: Drafted and wrote the manuscript, performed the biogas energy potential calculations and analyzed the results.

Semih Coşkun: Assisted in analysis, result interpretation and helped in manuscript preparation.

\section{Ethics}

There are no ethical issues after the publication of this manuscript.

\section{References}

1. Teixeira, T.R, Ribeiroa, C.A.A.S, Santos, A.R, Marcattic, G.E Lorenzon, A.S, Castro, N.L.M, Domingues, G.F, Leite, H.G, Menezes, S.J.M.C, Mota, P.H.S, Telles, L.A.A, Vieirac, R.S. 2018 Forest Biomass Power Plant Installation Scenarios, Biomass and Bioenergy; 108: 35-47.

2. Mao, G, Huang, N, Wang, H. 2018. Research on biomass energy and environment from the past to the future: A bibliometric analysis, Science of The Total Environment; 635: 1081-1090.
3. Akyürek, Z. 2019. Sustainable Valorization of Animal Manure and Recycled Polyester: Co-pyrolysis Synergy. Sustainability; 11(8): 2280 .

4. International Energy Agency, Key World Energy Statistics. https://www.iea.org/publications/freepublications/publication/Key World2017.pdf, 2017 (accessed at 07.05.2019).

5. Ferreira, L.R.A, Otto, R.B, Silva, F.P, De Souz, S.N.M, De Souz, S.S, Ando, Junior O.H. 2018. Review of the energy potential of the residual biomass for the distributed generation in Brazil, Renewable and Sustainable Energy Reviews; 94: 440-455.

6. Scalat, N, Dallemand, J.F, Fahl, F. 2018. Biogas: developments and perspectives in Europe, Renewable Energy; 129: 457-472.

7. Lyytimäki, J. 2018. Renewable energy in the news: Environmental, economic, policy and technology discussion of biogas, Sustainable Production and Consumption; 15: 65-73.

8. Republic of Turkey Ministry of Energy and Natural Resources, General Directorate of Renewable Energy, Biomass Energy Potential Map. http://bepa.yegm.gov.tr/, 2017 (accessed at 07.05.2019).

9. Akyürek, Z. 2018. Potential of Biogas Energy from Animal Waste in the Mediterranean Region of Turkey, Journal of Energy Systems; 2(4): 159-167.

10. World Energy Council, World Energy Resources Bioenergy, https://www.worldenergy.org/wpcontent/uploads/2017/03/WEResources_Bioenergy_2016.pdf, 2016 (accessed at 07.05.2019).

11. Food and Agricultural Organization of the United Nations, Water Pollution from Agriculture: A Global Review 2017, http://www.fao.org/3/a-i7754e.pdf, 2017 (accessed 07.05.2019).

12. Ayhan, A. 2016. Biogas potential from animal waste of Marmara Region-Turkey, Agronomy Research; 14(3): 650-660.

13. Ilgar, R. 2016. A Study for Determination of Biogas Potential in Çanakkale, Assets by Animals, Eastern Geographical Review; 35 : 89-106.

14. Eryilmaz, T, Yesilyurt, M.K, Gokdogan, O, Yumak, B, Determination of Biogas Potential from Animal Waste in Turkey: A Case Study for Yozgat Province. 2015. European Journal of Science and Technology; 2(4): 106-111.

15. Özer, B. 2017. Biogas energy opportunity of Ardahan city of Turkey, Energy; 139: 1144-1152.

16. Avcioglu, O, Turker, U. 2012. Status and potential of biogas energy from animal wastes in Turkey, Renewable and Sustainable Energy Reviews; 16: 1557-1561.

17. Turkish Statistical Institute, Livestock Population Database 2017. http://www.tuik.gov.tr/, 2017 (accessed at 07.05.2019).

18. Ozyurt, O. 2010. Energy issues and renewables for sustainable development in Turkey, Renewable and Sustainable Energy Reviews; 14: 2976-2985.

19. Intergovernmental Panel on Climate Change, IPCC Guidelines for national greenhouse gas inventories. https://www.ipccnggip.iges.or.jp/public/2006gl/, 2006 (accessed at 07.05.2019).

20. Intergovernmental Panel on Climate Change, Climate Change 2007: Synthesis Report. https://www.ipcc.ch/report/ar4/syr/, 2007 (accessed at 07.05.2019). 